\title{
Contextualizing Project Human Resources Management within Nigeria's Public University System: a case study of Federal University of Technology, Minna
}

\author{
${ }^{1}$ Ikechukwu A. Diugwu, ${ }^{2}$ Ashem E. Egila, ${ }^{3}$ Musa Mohammed
}

\begin{abstract}
Universities are incubators of skills, knowledge and ideas that trigger economic growth and stability. But this is dependent on the attitude of university staff (especially academic staff) towards their duties, a factor believed to be influenced by prevailing environmental factors. A range of factors that influence behaviour/performance of lecturers in federal universities in Nigeria were examined using survey questionnaire as an instrument. The analyses of respondents' views reveal, contrary to a generally held notion, that the nature of technology available and lack of recognition considerably affect performance, perhaps, more than poor remuneration, while comfort and nature of relationships (vertical and lateral) are key factors that enhance staff performance at work. The study recommends activities aimed at strengthening management-staff relationship as well as periodic performance evaluation of staff. The outcome of this study would serve as a guide for enhancing the performance of public universities in Nigeria by creating a work environment that enhances performance.
\end{abstract}

Key words: project, human resources management, motivation, university, work performance, recognition, relationship, reward.

\section{Introduction}

The development of any nation is hinged on her ability to harness and transform available human and material resources into value adding/enhancing products and services. Even though these two resources are essential for economic growth and stability, there are suggestions that, perhaps, human resources contribute more to the development of the society, whether at societal or individual level. This may have informed the suggestions by Faust (2010) that knowledge is replacing other resources as the main driver of economic growth. Again, there are views that acquisition of knowledge is a sustainable source of competitive advantage (Diugwu, 2011a, 2011b). And according to Zack (1999), knowledge is a valuable and strategic resource, and its application on problems becomes the most important capability, especially in today's society where economic growth and development are driven by the existence of requisite knowledge (Varghese, 2007).

Although man is endowed with innate knowledge, this has to be nurtured and harnessed for optimal benefit; this is only achievable through education (formal or informal). Education is the base upon which prosperity and social mobility are built on (Faust, 2010); a potent and vibrant instrument for development of nations (Aghenta, 2000; Fadipe, 2000; Olutola, 1983). According to Woodhall (1970), this impact could be attributed to the ability of the education process to increase the creative capacities of people. Having thus, established education as a route through which knowledge could be acquired and nurtured, it becomes necessary to establish the sources of education (and by implication, knowledge). Although formal education starts with the basic pre-primary and primary education, progressing through to the higher education/tertiary level, Varghese (2007) sees the higher education system as the main source of knowledge production, dissemination and absorption in any society. In the views of Sir Leszek Borysiewicz (2012), a key output of higher education institutions is human resources, with economic productivity as a by-product of teaching and research. Thus, the tertiary education system is able to promote growth and well-being by providing the high level skills and research output required in modern economies (OECD, 2011).

The above notwithstanding, there are suggestions that greater percentage of the contribution of the tertiary/higher education sector is made by Universities. For instance, Faust (2010) notes that higher education generates broader economic growth and individual prosperity; and universities, having contributed nearly $£ 60$ billion to the economy of United Kingdom between 2001 and 2008, for instance, have become key players in a global system that is increasingly driven by knowledge. This feat is woven around the fact that universities, as traditional carriers of advanced research and higher knowledge, play greater roles in enhancing knowledge production through the provision of the human resources and scientific results that could be turned into patents, products, and services (Power \& Malmberg, 2008).

In could be inferred from the foregoing that the university system has the training of skilled management manpower that can contribute to the development of the society as its core mandate. As noted in Power and Malmberg (2008), universities, through the education of students, could have a very real effect on the 
provision of labour. Additionally, the university system is expected to be a source from which new ideas emanate through cutting edge researches. In all these core functions, universities rely on their staff (academic and non-academic), who work within scope, cost, time, and quality constraints. Allusions to these constraints have been made in earlier works. In Nigeria for instance, although the education sector has multiple sources of fund, it is the Federal government that is the major funder of higher education, and quite expectedly, there is a competition with other sectors/sub-sectors for available limited resources (Harvey \& Jowsey, 2004). Within the education sub-sector, the fund allocated to universities is considered higher than that allocated to other levels of education. This has been attributed to increase in the number of universities (Moja, 2000). There are, however, observations that the fund allocated to the sector has not reflected inflation rates and the growing enrolment figures (Ejiaga, 1997).

It could be argued that the establishment of some universities in Nigeria was influenced by social and political pressures rather than economic considerations of manpower needs of the country. This amounts to poor conceptualization and has caused myriads of problems within the system to the extent that stakeholder needs have neither been satisfied, nor their expectations met. These are practical implications of poor application of project management principles. It is in recognition of these constraints and expectations that the university system is regarded in this paper as a project oriented one; and its activities can only be efficiently executed through the application of acceptable project management principles. As a result, the discussions in this paper would be guided by project human resource management principles (Gale, 2004; Huemann, Turner, \& Keegan, 2004; Project Management Institute, 2000). A critical assessment of the human resources aspect of the university system, especially in Nigeria, is important because in order to build intellectual capital, there is need to utilize "social capital", which is developed through the repeated interaction of people over time (Nahapiet \& Ghoshal, 1998). This further highlights the need to establish organizational cultures, forms and reward systems capable of enhancing and sustaining these social relationships (Quinn, Anderson, \& Finkelstein, 1996). This cannot be effectively done without first, establishing those factors that impact on the performance of staff, as performance is shaped by prevailing environmental factors (New \& Payne, 1995).

Nigeria's university education sector

\section{Literature Review}

Universities have been described variously (Brickel, 1975; Brubacher, 1982; Privateer, 1999). However, as highlighted by Kerr ( 2001), all these views have a commonality - that is, that universities engage simultaneously in teaching, research, manpower development, as well as community oriented services. Thus, Universities are visualized as places for higher education and basic research; and although they serve these traditional functions, well-resourced universities play leading roles in successful economies around the world (ICF Consulting, 2003). Consequently, the establishment of universities could have been motivated by the need to train middle to high-level manpower that would spearhead nation building. And, as Borysiewicz (2012) puts it, Universities produce human resources whose activities lead to higher productivity. This is not different in Nigeria's case where universities are expected to producj the right type of manpower in sufficient quantity and quality needed to transform the nation from a developing country to a developed country (Fadipe, 2000).

There are about three hundred and sixty five (365) higher education institutions (HEIs) in Nigeria, made up of 104 Universities; 121 monotechnics and polytechnics; (85) Colleges of Education (CoE), and 65 Innovative Enterprises (Shu'ara, 2010) . However, information from the National Universities Commission's website (the regulator in charge of Universities in Nigeria) shows that the number of Universities has increased to 128 (40 Federal; 38 State; 51 Private). Table 1below which profiles the routes to tertiary education in Nigeria clearly shows that prospective students prefer studying in universities to monotechnics, polytechnics and colleges of education. In view of this, the focus of this paper shall be on university sub-sector (at Federal level) in view of the population that they serve.

Table 1: Routes to tertiary education, 2007 - 2010

\begin{tabular}{cccc}
\hline Year & $\begin{array}{c}\text { University } \\
\text { Matriculation } \\
\text { Examination } \\
\text { (UTME) }\end{array}$ & $\begin{array}{c}\text { Monotechnics, } \\
\text { Polytechnics \& } \\
\text { Colleges of } \\
\text { Education } \\
\text { (MPCE) }\end{array}$ & Total \\
\hline 2007 & 911,679 & 167,836 & $1,079,515$ \\
2008 & $1,192,050$ & 310,022 & $1,502,072$ \\
2009 & $1,184,651$ & 342,908 & $1,527,559$ \\
2010 & $1,330,531$ & 45,140 & $1,375,671$ \\
Total & $4,618,911$ & 865,906 & $5,484,817$ \\
$\%$ (Total) & $84 \%$ & $16 \%$ & \\
\hline
\end{tabular}

Source: Shu'ara (2010) 
Available data which dates back to the 1962/63 academic session show continual increases in the number of institutions, students' enrolment, as well as graduate output (National Universities Commission, 1994; Shu'ara, 2010). On the other hand, there has not been a commensurate increase in budgets; a situation that forced expenditures per full time equivalent (FTE) down to \$362 in 1998, from \$700 in 1991 (Jibril, 1999). The observation by Ajayi and Akindutire (2007) that the demand for admission is higher than what the system's physical capacity can accommodate in terms of personnel and infrastructure is supported by views that the lingering financial crises has hampered the provision of these resources (UNESCO, 2004). This has negatively impacted on the system. For instance, it may have caused the shortage of academic staff in our universities (Federal Ministry of Education, 2003; Shu'ara, 2010) due to the migration of academic staff to other institutions or countries in search of better remuneration and conditions of service (Bangura, 1994; Saint, Hartnett, \& Strassner, 2003). The consequence of the above is that the remaining academic staff are over-worked and intellectually jaundiced (Ukeje \& Ehiametalor, 1998). Furthermore, this shortage, according to Shu'ara (2010), is such that over $60 \%$ of academic staff, particularly in the critical areas of science and technology, are at Lecturer 1 or below cadre; this has enormous implications on the quality of teaching and learning.

In view of the above, any doubts about the ability of Nigerian universities to live up to this expectation would be well founded. This perhaps informed the description of the Nigerian higher education system by Moja (2000) as inefficient and ineffective. This is demonstrated by the decline in quality due to the unstable environment occasioned by frequent strikes by students or staff, as well as the quality of the academics recruited among other factors. This necessitates rethinking quality promotion in the nation's education sector. These factors, shortage of quality staff as well as frequent strikes, are undoubtedly linked to job satisfaction and motivation.

\section{An Overview of Motivation and Job Satisfaction}

Motivation is a psychological process that causes the arousal, direction, intensity and persistence of behaviour (E. A. Locke \& Letham, 2004). Within the context of a work environment, the concept of motivation explains why workers behave in certain ways; the psychological forces that determine the direction of a person's behaviour, level of effort and tenacity (George \& Jones, 2011). Therefore, motivation, as an in-built human trait, needs to be aroused and sustained with a view to aligning employees' behaviour with that of the organization (Mawoli \& Babandako, 2011). Although motivation is a complex phenomenon, with many competing and perhaps inconclusive theories (see for instance, Harder (2008)), it helps in addressing issues relating to employee performance. The various views about motivation have been encapsulated into the content or process/cognitive perspectives/theories. The content theories emphasise what motivates individuals by identifying their needs, relative strengths, and the goals they pursue so as to satisfy these needs. Process theories on the other hand emphasize the process of motivation, looking specifically at the various variables which help initiate, direct and sustain behaviour. Table 2 below summarizes these broad classifications of motivation.

Table 2: Classification of theories of motivation

\begin{tabular}{|c|c|c|c|}
\hline & Classification & Summary of theory & Examples \\
\hline \multirow[t]{2}{*}{$\begin{array}{l}\text { Content } \\
\text { Theory: }\end{array}$} & (a) Needs theory: & $\begin{array}{l}\text { The ability of a job to meet the } \\
\text { specific needs of individuals is a } \\
\text { motivating factor }\end{array}$ & $\begin{array}{l}\text { (i) Abraham Maslow's hierarchy of } \\
\text { needs } \\
\text { (ii) Clayton Alderfer's ERG theory } \\
\text { (iii) McClelland's learned Needs } \\
\text { Model }\end{array}$ \\
\hline & $\begin{array}{l}\text { (b) Job content } \\
\text { theory }\end{array}$ & $\begin{array}{l}\text { Only those aspects that are related } \\
\text { to job content (achievement, } \\
\text { recognition, responsibility, } \\
\text { supervision, relationship, } \\
\text { advancement) that satisfy and } \\
\text { motivate people to work. }\end{array}$ & $\begin{array}{l}\text { (i) Herzberg's Two Factor Model } \\
\text { (ii) Hackman and Oldham }\end{array}$ \\
\hline \multicolumn{2}{|c|}{ (2) Process/Cognitive theory } & $\begin{array}{l}\text { Deals with 'how' and 'why' } \\
\text { people are motivated }\end{array}$ & $\begin{array}{l}\text { (i) Vroom's Expectancy theory } \\
\text { (ii) Adam's Equity theory } \\
\text { (iii) Locke's Goal Setting theory } \\
\text { (iv) Skinner's Reinforcement theory }\end{array}$ \\
\hline
\end{tabular}

While motivation cannot be directly measured, factors such as satisfaction/no-satisfaction and dissatisfaction/no-dissatisfaction factors that could be used in measuring it have been identified (F. Herzberg, 1974). Mullins (1996) notes that factors which lead to satisfaction include achievement, recognition, the work itself, responsibility, achievement, growth; while factors that lead to dissatisfaction are company policies, supervision, relationships with supervisor/peers, work conditions, salary, status, security among others. These factors could either minimize the level of dissatisfaction (Jaafar, Ramayah, \& Zainal, 2006), or affect a person's desire to do a good job (Nelson \& Quick, 2003). 
The level of satisfaction or dissatisfaction derived from a job (or job satisfaction) is a widely researched topic in organisational behaviour (Lumley, Coetzee, Tladinyane, \& Ferreira, 2011; Spector, 1997). This assertion is given credence by the numerous, albeit, varying descriptions and definitions of job satisfaction (George \& Jones, 2011; Hoppock, 1935; Edwin A. Locke \& Latham, 1990; Vroom, 1964). This notwithstanding, job satisfaction simply conveys an individual's perception or understanding that work is not a necessity imposed upon him or her; an indication of the degree to which that individual feels that he or she is positively or negatively affected by his/her job (Ifinedo, 2005). It is obvious from available literature that perception about a job and its different aspects play a huge role in the level of productivity. This basically, is what the study of job satisfaction is all about (Gibson, Ivancevich, \& Donnelly, 2000; Luthans, 2002; Spector, 1997). Job satisfaction according to F. A. Herzberg, Mausner, and Snyderman (1962) is emotional response to one's tasks, as well as the physical and social conditions of the workplace. There are equally observations that job satisfaction is influenced by a range of intrinsic and extrinsic outcomes (rewards) offered by a job (Cheung \& Scherling, 1999; Gibson et al., 2000); a feeling of happiness or unhappiness associated with a particular job or the job holder's expressed views about the job (Gibson et al., 2000). Although motivation is that invisible, internal and hypothetical construct that can neither be seen nor measured directly (Pinder, 1998), it could manifest in the level of satisfaction derived from doing a particular job; known to impact on organisational performance (Begley \& Czajka, 1993; Morrison, 2008; Tharenou, 1993). In the education sector, it is has been blamed for teacher attrition (Russ, Chiang, Rylance, \& Bongers, 2001), the situation where teachers leave the classroom to take up other professional responsibilities, inside or outside of education, or to spend more time with their families (Miller \& Chait, 2008).

There are suggestions that although motivation and job satisfaction are related, they are distinct phenomena (Gibson et al., 2000; Peretomode, 1991). A further inference from these sources is that motivation is focused essentially on the behavior of the individual, while job satisfaction relates to the level of fulfillment derived from specific job responsibilities. In view of this distinction, efforts have been made to establish a link (if any) between an individual's level of motivation and the degree to which that individual is satisfied with his/her job. Among other research studies, Ahmed and Islam (2011) for instance, concluded from their study that a positive association exists between motivation and job satisfaction.

The level of satisfaction derived from a job could trigger off emotional reactions (caused either by personal or organizational factors) that could affect organizational commitment (Mowday, Steers, \& Porter, 1979). These personal factors are those regarded by employees as being important to them (Sempane, Rieger, \& Roodt, 2002). For instance, whereas a clearly defined job description is an motivator, an unclear job description and irrelevant administrative assignments can overburden staff, thus which causing dissatisfaction among them (Fuhrmann, 2006). This is closely aligned with the view expressed by Davidson (2007) regarding high work load and non teaching activities as specific job design problems. Therefore, in line with Lynn (2002), there is a need to provide professional learning and growth opportunities capable of motivating teachers and enhancing their performances. It is also instructive to note that in view of the link between the level of staff turnover and absenteeism in work established in Porter and Steers (1973), the moment an employee feels that his/her input are greater than outputs, that employee becomes de-motivated (Adams, 1963). This could increase the desire to satisfy basic human needs (lower-order motivators), increase susceptibility to corrupt tendencies, fraudulent activities, including robbery among some workers (Karwai, 2005). In the education factor, several sources have shown that a link exists between job satisfaction and attrition (Russ et al., 2001); a situation that could be triggered or worsened by lack of recognition, few opportunities for promotion, excessive paperwork, loss of autonomy, lack of supplies, low pay, and stressful interpersonal interactions (Wisniewski \& Gargiulo, 1997). On the other hand, job satisfaction leads to better performance by students, possibly caused by enhanced teacher effectiveness (Ashton \& Webb, 1986).

An employee who is not satisfied with his/her job, quite expectedly, impacts negatively on the entire system. And within the higher education sector of countries such as Nigeria, these include low lecturer output, high staff turnover, regular strike actions, poor students' performance and lecturer absenteeism (Adelabu, 2005). Within the Nigerian education sector, Ololube $(2006,2007)$ identifies limited professional advancement opportunities and low salary (causing them to keep other jobs to supplement their earnings) as major causes of job dissatisfaction among teachers.

\section{Methodology}

With a view to achieving the objective of this study, a descriptive survey approach utilising close ended questionnaires for data collection was adopted. The research population considered was only the academic staff $(\mathrm{N}=833)$ of the Federal University of Technology Minna.

The sample size was calculated using the following formula (equation 1) proposed by Cochran (1977): 


$$
n_{0}=\frac{z^{2} p q}{e^{2}}
$$

where
$\mathrm{n}_{0} \quad$ is the sample size
$\mathrm{z} \quad$ is the standard normal variable (1.96 at $95 \%$ confidence level)
$\mathrm{p} \quad$ is the proportion or degree of variability $(50 \%$ or 0.5$)$
$\mathrm{q} \quad$ is the which is equal to (1-p)
$\mathrm{e} \quad$ is the level of precision $(5 \%$ or 0.05$)$

The solution to the above formula shows that a sample size $\left(\mathrm{n}_{0}\right)$ of 384 is required.

However, the above formula is more appropriate when dealing with a large population. As such, for a small population size a finite population factor (fpc) shown in equation 2 is applied (Cochran, 1977; Kish, 1965):

$$
f p c=\sqrt{\frac{N-n_{0}}{N-1}},
$$

where

$\mathrm{fpc} \quad$ is the finite population factor

$N \quad$ is the population size

$\mathrm{n}_{0} \quad$ is the sample size from equation 1 above

According to Kish (1965), equation 2 above should be applied when a sample size exceeds $10 \%$ of the population size $\mathrm{N}$ (in this case 833); upon which a revised population size should be calculated using equation 3 below:

where

$$
n_{R}=\frac{n_{0}}{1+\frac{\left(n_{0}-1\right)}{N}}
$$

$\mathrm{n}_{R} \quad$ is the revised sample size based on the fpc

$N \quad$ is the population size

$\mathrm{n}_{0} \quad$ is the sample size from equation 1 above

Solving equation 3 above yields a revised sample size of 263. A further 30\% (78.91) of this figure was added to compensate for non-responses (Israel, 1992), making the total number of questionnaires distributed to be 341 .

\section{Results And Discussion}

Out of the 341 questionnaires that were administered, 189 were returned, representing a $56 \%$ response rate; which is adjudged reasonable. A basic frequency analysis and analysis of variance (ANOVA) were carried out using SPSS software.

Distribution of Respondents

Table 4 below shows the distribution of respondents according to (a) rank, and (b) salary. The percentages shown are based on the number of valid responses.

Table 4: Distribution of respondents

(a) Responses grouped according to rank

\begin{tabular}{|l|c|c|}
\hline Rank & Frequency & Valid Percent \\
\hline Professor & 7 & 4.9 \\
\hline Associate Professor & 9 & 6.3 \\
\hline Senior Lecturer & 23 & 16.0 \\
\hline Lecturer I & 34 & 23.6 \\
\hline Lecturer II & 46 & 31.9 \\
\hline Assistant Lecturer & 18 & 12.5 \\
\hline Graduate Assistant & 7 & 4.9 \\
\hline Valid Responses & 144 & 100.0 \\
\hline Missing & 45 & \\
\hline Total & 189 & \\
\hline
\end{tabular}

(b) Responses grouped according to salary range

\begin{tabular}{|l|c|c|}
\hline Salary Range ( ) & Frequency & Valid Percent \\
\hline $18000-49999$ & 10 & 5.5 \\
\hline $50000-99999$ & 34 & 18.7 \\
\hline $100000-149999$ & 59 & 32.4 \\
\hline $150000-199999$ & 17 & 9.3 \\
\hline 200000 and above & 62 & 34.1 \\
\hline Valid Responses & 182 & 100.0 \\
\hline Missing & 7 & \\
\hline Total & 189 & \\
\hline
\end{tabular}


There are 45 and 7 missing cases recorded from the rank of respondents and salary range respectively. These missing cases were not followed up because for confidentiality purposes, there was no provision for identity of respondents. Secondly, the response rate achieved was adjudged reasonable enough for the purposes of the study.

\section{Impact of Work Environment on Performance}

A one-way between groups analysis of variance (ANOVA) was conducted to compare the effect of work environment (comfort, structure, relationship, recognition, empowerment, and autonomy) on staff performance.

Table 5: ANOVA Result of Influence of Work Environment on Staff Motivation

\begin{tabular}{lcccccc}
\hline & & & & Mean & \\
& & Sum of Squares & df & Square & F & Sig. \\
\hline Comfort & Between Groups & 114.509 & 6 & 19.085 & 7.348 & .000 \\
& Within Groups & 350.646 & 135 & 2.597 & & \\
Structure & Total & 465.155 & 141 & & & \\
& Between Groups & 43.557 & 6 & 7.260 & 3.181 & .006 \\
Relationship & Within Groups & 296.691 & 130 & 2.282 & & \\
& Total & 340.248 & 136 & & & \\
& Between Groups & 8.494 & 6 & 1.416 & .774 & .592 \\
Recognition & Within Groups & 241.520 & 132 & 1.830 & & \\
& Total & 250.014 & 138 & & & \\
& Between Groups & 46.054 & 5 & 9.211 & 5.706 & .000 \\
& Within Groups & 145.280 & 90 & 1.614 & & \\
Empowerment & Total & 191.333 & 95 & 3 & & \\
& Between Groups & 47.392 & 6 & 7.899 & 2.987 & .009 \\
& Within Groups & 343.732 & 130 & 2.644 & & \\
& Total & 391.124 & 136 & & & \\
& Between Groups & 34.273 & 6 & 5.712 & 2.122 & .055 \\
& Within Groups & 349.960 & 130 & 2.692 & & \\
& Total & 384.234 & 136 & & & \\
& & & & &
\end{tabular}

It could be seen that from Table 5 above that at the $\mathrm{p}<.05$ level, there are statistically significant different among the ranks regarding the variables as follows: comfort - $[\mathrm{F}(6,135)=7.348, \mathrm{p}=0.000]$; structure- $[\mathrm{F}(6,130)=3.181, \mathrm{p}=0.006]$; recognition $-[\mathrm{F}(5,90)=5.706, \mathrm{p}=$

$0.000]$; and empowerment- $[\mathrm{F}(6,130)=2.987, \mathrm{p}=0.009]$. There is, however, no statistical difference in the perception of respondents with regards to the variables, relationship - $[\mathrm{F}(6,132)=.774, \mathrm{P}=0.592]$; autonomy $[\mathrm{F}(6,130)=2.122, \mathrm{P}=0.055]$.

Table 6: Post Hoc Comparison of Selected factors using Tukey HSD method

\begin{tabular}{|c|c|c|c|c|c|c|c|}
\hline Factors & Rank & Mean & $\begin{array}{c}\text { Std. } \\
\text { Deviation }\end{array}$ & Factors & Rank & Mean & $\begin{array}{c}\text { Std. } \\
\text { Deviation }\end{array}$ \\
\hline \multirow[t]{7}{*}{ Comfort } & Professor & 3.14 & 1.464 & Recognition & Professor & . & \\
\hline & Associate Professor & 1.44 & .882 & & Associate Professor & 4.00 & .000 \\
\hline & Senior Lecturer & 2.39 & 1.751 & & Senior Lecturer & 4.13 & 1.586 \\
\hline & Lecturer I & 2.91 & 2.115 & & Lecturer I & 5.07 & 1.530 \\
\hline & Lecturer II & 2.26 & 1.584 & & Lecturer II & 3.77 & 1.107 \\
\hline & Assistant Lecturer & 1.83 & .857 & & Assistant Lecturer & 5.67 & .488 \\
\hline & Graduate Assistant & 6.00 & .000 & & Graduate Assistant & 4.43 & .976 \\
\hline \multirow[t]{7}{*}{ Structure } & Professor & 2.29 & .488 & Empowerment & Professor & 1.86 & 1.464 \\
\hline & Associate Professor & 3.78 & .441 & & Associate Professor & 2.33 & .866 \\
\hline & Senior Lecturer & 4.00 & 1.567 & & Senior Lecturer & 3.00 & 1.784 \\
\hline & Lecturer I & 4.13 & 1.661 & & Lecturer I & 3.72 & 1.611 \\
\hline & Lecturer II & 3.20 & 1.706 & & Lecturer II & 3.48 & 1.947 \\
\hline & Assistant Lecturer & 2.67 & 1.291 & & Assistant Lecturer & 3.00 & .845 \\
\hline & Graduate Assistant & 3.43 & .976 & & Graduate Assistant & 4.71 & .488 \\
\hline
\end{tabular}


For those variables where statistical differences were observed, a post hoc comparison of the factors using the Tukey HSD was carried out to ascertain the sources of the observed differences. The test results (Table 6 above) show that the mean score views of graduate assistants $(\mathrm{M}=6.00, \mathrm{SD}=0.000)$ were statistically significantly different from those of professors $(\mathrm{M}=3.14, \mathrm{SD}=1.464)$, associate professors $(\mathrm{M}=1.44, \mathrm{SD}=$ $0.882)$, senior lecturers $(M=2.39, \mathrm{SD}=1.751)$, lecturer $\mathrm{I}(\mathrm{M}=2.91, \mathrm{SD}=2.115)$, lecturer $\mathrm{II}(\mathrm{M}=2.26, \mathrm{SD}=$ $1.584)$, assistant lecturers $(\mathrm{M}=1.83, \mathrm{SD}=0.857)$.

The result of the Tukey HSD multiple comparisons analysis (Table 7) shows the sources of the observed statistical differences. Whereas the observed statistical significant differences in comfort could be explained by all the ranks (significance values $<0.05$ ), the correlation in terms of structure emanates from the perceptions of Assistant Lecturer and Lecturer I's which shows a mean difference of -1.458 and a significance value of 0.039 . In terms of perceptions about empowerment, it is explained for by the independent variables, graduate assistants and professors, with a mean difference of 2.857 and a significance value of 0.022 . On aggregate, these results suggest that the performance of staff of public universities in Nigeria is affected by their work environment. See also Appendix 1 for more on sources of identified statistical differences.

Table 7: Post Hoc Comparison of Selected factors using Tukey HSD method

\begin{tabular}{|c|c|c|c|c|c|c|c|}
\hline \multirow{2}{*}{$\begin{array}{l}\text { Dependent } \\
\text { Variable }\end{array}$} & \multirow[b]{2}{*}{ (I) Rank } & \multirow[b]{2}{*}{ (J) Rank } & \multirow{2}{*}{$\begin{array}{c}\text { Mean } \\
\text { Difference (I-J) }\end{array}$} & \multirow[b]{2}{*}{ Std. Error } & \multirow[b]{2}{*}{ Sig. } & \multicolumn{2}{|c|}{$95 \%$ Confidence Interval } \\
\hline & & & & & & Lower Bound & Upper Bound \\
\hline \multirow[t]{6}{*}{ Comfort } & \multirow{6}{*}{$\begin{array}{l}\text { Graduate } \\
\text { Assistants }\end{array}$} & Professor & $2.857^{*}$ & .861 & .020 & .28 & 5.44 \\
\hline & & Associate Professor & $4.556^{*}$ & .812 & .000 & 2.12 & 6.99 \\
\hline & & Senior Lecturer & $3.609^{*}$ & .696 & .000 & 1.53 & 5.69 \\
\hline & & Lecturer I & $3.094^{*}$ & 672 & .000 & 1.08 & 5.11 \\
\hline & & Lecturer II & $3.739^{*}$ & .654 & .000 & 1.78 & 5.70 \\
\hline & & Assistant Lecturer & $4.167^{*}$ & .718 & .000 & 2.02 & 6.32 \\
\hline \multirow[t]{6}{*}{ Structure } & \multirow{6}{*}{$\begin{array}{l}\text { Assistant } \\
\text { Lecturer }\end{array}$} & Professor & .381 & .692 & .998 & -1.69 & 2.45 \\
\hline & & Associate Professor & -1.111 & .637 & .588 & -3.02 & .80 \\
\hline & & Senior Lecturer & -1.333 & .501 & .117 & -2.83 & .17 \\
\hline & & Lecturer I & $-1.458^{*}$ & .473 & .039 & -2.87 & -.04 \\
\hline & & Lecturer II & -.538 & .452 & .896 & -1.89 & .81 \\
\hline & & Graduate Assistants & -.762 & .692 & .927 & -2.83 & 1.31 \\
\hline \multirow[t]{6}{*}{ Empowerment } & \multirow{6}{*}{$\begin{array}{l}\text { Graduate } \\
\text { Assistants }\end{array}$} & Professor & $2.857^{*}$ & .869 & .022 & .25 & 5.46 \\
\hline & & Associate Professor & 2.381 & .819 & .064 & -.07 & 4.84 \\
\hline & & Senior Lecturer & 1.714 & .702 & .190 & -.39 & 3.82 \\
\hline & & Lecturer I & .996 & 678 & .764 & -1.04 & 3.03 \\
\hline & & Lecturer II & 1.237 & .662 & .504 & -.74 & 3.22 \\
\hline & & Assistant Lecturer & 1.714 & .744 & .250 & -.51 & 3.94 \\
\hline
\end{tabular}

*. The mean difference is significant at the 0.05 level.

Post hoc tests are not performed for Recognition because at least one group has fewer than two cases

The respondents were given opportunities to express their feelings on a range of issues. An analysis of these comments gives further insight into what motivates/de-motivate staff. For instance, a response by one Professor shows a need for a comfortable work environment; and engendering closer relationships among all stakeholders is a subset of this. An Assistant Lecturer observed that it should be comfort first, because this enhances effective research and learning, thereby positively impacting knowledge transmission and acquisition. Also, a Lecturer II observed that "... good working relations amongst staff helps to reduce working challenges".

It is worth noting that the extent to which an individual or group has been given authority or power to make critical decisions affect the level of perfomance. It is therefore not a coincident that there is no statistically significant difference across the ranks regarding empowerement. Kirkman, Rosen, Tesluk, and Gibson (2004) for instance, established a positive relationship between empowerement and performance; such that empowerement has been linked to the desire to continuously improve not only on existing practice(s), but also on the level of commitment.

\section{Factors Affecting Performance}

An ANOVA test of factors that hinder work performance was carried out. The results (Table 8 below) show that there is no statistically significant difference among respondents on how poor remuneration $(\mathrm{P}$-value of .443 at the 0.05 level of significance) as well as meaningful work and supervision $(\mathrm{p}=.137$ at the 0.05 significance level) affected performance at work. Similarly, the results show there are statistical differences in 
the means of how nature of technology available for work, lack of recognition, unnecessary bureaucracy, meaningful work and supervision, as well as inadequate training at the 0.05 level significance level. This could be seen as an indication that these factors are major hindrances to work performance.

Table 8: Major Hindrances to Work Performance

\begin{tabular}{lcccccc}
\hline & & Sum of & Mean & & \\
& & Squares & df & Square & F & Sig. \\
\hline Nature of technology available for work & Between Groups & 37.830 & 6 & 6.305 & 2.414 & .030 \\
& Within Groups & 331.752 & 127 & 2.612 & & \\
& Total & 369.582 & 133 & & & \\
Lack of recognition & Between Groups & 55.447 & 6 & 9.241 & 4.269 & .001 \\
& Within Groups & 274.911 & 127 & 2.165 & & \\
& Total & 330.358 & 133 & & & \\
Unnecessary bureaucracy & Between Groups & 54.650 & 6 & 9.108 & 3.457 & .003 \\
& Within Groups & 355.724 & 135 & 2.635 & & \\
Poor remuneration & Total & 410.373 & 141 & & & \\
& Between Groups & 14.717 & 6 & 2.453 & .993 & .433 \\
& Within Groups & 308.761 & 125 & 2.470 & & \\
Meaningful work and supervision & Total & 323.477 & 131 & & & \\
& Between Groups & 18.529 & 6 & 3.088 & 1.656 & .137 \\
& Within Groups & 236.845 & 127 & 1.865 & & \\
Inadequate training & Total & 255.373 & 133 & & & \\
& Between Groups & 189.544 & 6 & 31.591 & 11.542 & .000 \\
& Within Groups & 347.590 & 127 & 2.737 & & \\
\hline
\end{tabular}

The ANOVA test procedure was also used to test the general feelings of staff towards their motivation. The results (between groups) are presented in Table 9. From the table, it is clear that the P-values indicate no difference for sponsorship of social events which is .122 at 0.05 levels, signifying that this variable has minimal effect on staff motivation. The P-value for the remaining variables is negligible which indicates their strong connection to staff motivation.

However, in considering the causes of hindrance within the work place, using the overall ranking, the nature of technology and lack of recognition were surprisingly rated high, more than poor enumeration. A respondent felt that non-availability of required technology and inadequate training on available technology have greatly affected the staff output. There are both intrinsic and extrinsic factors responsible for this. Making reference to this, a graduate assistant observed that "poor and obsolete technologies, poor training on how to use new technology act as disincentive to work and discourage people." There are also views that the irregular and erratic power (electricity) supply in Nigeria is also major hindrance to technological uptake. The nature of technology available manifests in physical aspects of machine equipment, process and work lay out and the actual method, system and procedure involved in carrying out a work schedule. It influences the level and extent of social interaction among workers. Information technology (IT) also influences the pattern of work; changing the function, structure of group work, as well as the nature of supervision. A Professor observed that "students in Nigerian higher education institutions learn about technologies rather than with technologies. Simply put they are only taught theories and little or no practical ..."

Lack of recognition is equally a hindrance. Some lecturers feel that even though teaching ought to be a noble profession, it is not duly recognized and accorded such respect by the society at large because of government's attitude towards the profession. The need for proper recognition and appreciation of efforts has been variously recognised (Aslam, 2011).

Some believe that apart from staff salary, other needs which enhance unity should be given adequate consideration. This implies that nature of relationship that exists within a work environment is seen as having a significant impact on the ability of staff to perform effectively. Relationship could be developed along several lines. For instance, it could be linear in nature, whereby authority flows vertically down the structure. It could also be along functional lines (applicable to specialist or advisory positions); involve the delegation of authority and responsibility for a specific activity; or laterally between individuals of different department but usually of the same level (Mullins, 1996). 
Table 9: General Feelings of Staff towards their Motivation ANOVA

\begin{tabular}{lccccc}
\hline & Sum of & & Mean & & Sig. \\
& Squares & df & Square & F & .000 \\
\hline Develop friendly atmosphere & 3.452 & 6 & .575 & 4.530 & .1201 \\
Sponsor social events & 7.207 & 6 & 1.201 & 1.717 & .122 \\
Minimum supervision & 45.879 & 6 & 7.647 & 7.540 & .000 \\
Policies de-motivate staff & 33.925 & 6 & 5.654 & 6.824 & .000 \\
Policies targeted at individuals & 25.373 & 6 & 4.229 & 3.793 & .002 \\
Adequate equipment & 7.099 & 6 & 1.183 & 5.198 & .000 \\
More visibility to management & 18.651 & 6 & 3.109 & 4.577 & .000 \\
Better job description & 5.324 & 6 & .887 & 4.108 & .001 \\
Assessment of performance & 20.442 & 6 & 3.407 & 8.939 & .000 \\
Subordinate assessment of performance & 41.591 & 6 & 6.932 & 10.031 & .000 \\
Employee is no longer interested in work & 76.500 & 6 & 12.750 & 9.653 & .000 \\
Suffering from too much work & 41.079 & 6 & 6.847 & 4.077 & .001 \\
Work is source of satisfaction and pleasure & 13.817 & 6 & 2.303 & 2.269 & .041 \\
\hline
\end{tabular}

\section{Conclusion and Recommendations}

This paper has explored key critical factors that affect motivation of employees of public universities in Nigeria. There are indications, and or pointers that lack of understanding and limited management commitment is affecting the ability of the universities to improve employee worker satisfaction. It was established that factors such as level of comfort, administrative structure, type of relationship with others, recognition, empowerment, as well as autonomy impact on output of employees. However, it was revealed that these affect the different ranks differently.

It thus follows that in order to improve productivity of employees, Management of public universities should strive, for instance, to create and maintain friendly atmosphere among their staff. There is also a need to improve technology available for work. A form of recognition/appreciation, in the form of merit award (which must not be monetary) amongst academic staff within the university would help increase dedication. This can be achieved by a strategic implementation of a monitoring and evaluations system that can automatically detect lecturer's achievement which would be integrated into the university system.

\section{Reference}

[1]. Adams, S. J. (1963). Towards an understanding of inequity. The Journal of Abnormal and Social Psychology, $67(5), 422-436$.

[2]. Adelabu, M. A. (2005). Teacher motivation and incentives in Nigeria. London: DFID.

[3]. Aghenta, J. A. (2000). Educational planning: a turning point in education and development in Nigeria Inaugural Lecture Series 58. Benin City: University of Benin.

[4]. Ahmed, I., \& Islam, T. (2011). Relationship between motivation and job satisfaction: a study of higher educational institutions. Journal of Economics and Behavioral Studies, 3(2), 94-100.

[5]. Ajayi, I. A., \& Akindutire, I. O. (2007). The unresolved issued of quality assurance in Nigerian universities. Journal of Sociology and Education in Africa, 6(1), 14-25.

[6]. Ashton, P. T., \& Webb, R. B. (1986). Making a difference: teachers' sense of efficacy and student achievement (Illustraed ed.): Longman.

[7]. Aslam, H. D. (2011). Performance Evaluation of Teachers in Universities: Contemporary Issues and Challenges. Journal of Educational and Social Research, 1(2).

[8]. Bangura, Y. (1994). Intellectuals, Economic Reform and Social Change: Constraints and Opportunities in the Formation of a Nigerian Technocracy. Development and Change, 25(2), 261-305. doi: 10.1111/j.1467-7660.1994.tb00516.x

[9]. Begley, T. M., \& Czajka, J. M. (1993). Panel analysis of the moderating effects of commitment on satisfaction, intent to quit and health following organisational change. Journal of Applied Psychology, 78(4), 552-556.

[10]. Borysiewicz, L., Sir. (2012). The research university of the future A keynote speech at the LERU 10th Anniversary Conference, Barcelona,

[11]. Brickel, A. M. (1975). The Aims of Education and the Proper/Standard of the University. In P. Seabury (Ed.), Universities in the Western World. New York: The Free Press.

[12]. Brubacher, J. S. (1982). On the philosophy of higher education (Revised ed.). San Francisco: Jossey-Bass.

[13]. Cheung, C.-K., \& Scherling, S. A. (1999). Job satisfaction, work values, and sex differences in Taiwan's organizations. The Journal of Psychology, 133(5), 563-575.

[14]. Cochran, W. G. (1977). Sampling techniques (3rd ed.). New York: John Wiley \& Sons.

[15]. Davidson, E. (2007). The Pivotal Role of Teacher Motivation in Tanzanian Education. The Educational Forum, 71(2), 157-166. doi: $10.1080 / 00131720708984928$

[16]. Diugwu, I. A. (2011a). Building competitive advantage of small and medium sized enterprises through knowledge acquisition and Sharing. KCA Journal of Business Management, 3(3), 102-120. 
[17]. Diugwu, I. A. (2011b, 27-28 October). Knowledge acquisition and sharing: a sustainable source of competitive advantage in supply chains. Paper presented at the 8th International Conference on Intellectual Capital, Knowledge Management and Organisational Learning (ICICKM), The Institute for Knowledge and Innovation Southeast Asia (IKI-SEA) of Bangkok University, Bangkok, Thailand.

[18]. Ejiaga, R. (1997). Higher education and the labor market: a study of University access and graduate employment opportunities in Nigeria. (Doctor of Philosophy Doctoral Thesis), Stockholm University, Stockholm University. Retrieved from http://urn.kb.se/resolve?urn=urn:nbn:se:su:diva-61884

[19]. Fadipe, J. O. (2000). Education for national development: The millennium option. In J. O. Fadipe \& E. E. Oluchkwu (Eds.), Educational Planning and Administration in Nigeria in the 21st Century (pp. 19-32). Nigeria: NIEPA.

[20]. Faust, D. G. (2010). The role of the University in a changing world: Royal Irish Academy, Trinity College Dublin.

[21]. Federal Ministry of Education. (2003). Education Sector Status Report. Abuja: Federal Ministry of Education/UNESCO.

[22]. Fuhrmann, T. (2006). Motivating Employees. WCDS Advances in DaIry Technology, 18, 93-101.

[23]. Gale, A. (2004). Competencies: organizational and personal. In P. W. G. Morris \& J. K. Pinto (Eds.), Wiley Guide to Managing Projects. Hoboken, New Jersey and Canada: John Wiley \& Sons, Inc.

[24]. George, J. M., \& Jones, G. R. (2011). Understanding and Managing Organizational behavior (6 ed.). New Jersey: Pearson/Prentice Hall.

[25]. Gibson, J. L., Ivancevich, J. M., \& Donnelly, J. H. (2000). Organizations: behavior, structure, processes (10 ed.): Irwin/McGrawHill.

[26]. Harder, M. (2008). How Do Rewards and Management Styles Influence the Motivation to Share Knowledge? Centre for Strategic Management and globalization (SMG) Working Paper No. 6

[27]. Harvey, J., \& Jowsey, E. (2004). Urban Land Economics. New York: Palgrave Macmillan.

[28]. Herzberg, F. (1974). Work and the nature of man: Granada Publishing Ltd.

[29]. Herzberg, F. A., Mausner, B., \& Snyderman, B. (1962). The motivation to work. New York: John Wiley.

[30]. Hoppock, R. (1935). Job Satisfaction. New York: Harper and Brothers.

[31]. Huemann, M., Turner, R., \& Keegan, A. (2004). Managing human resources in the project-oriented company. In P. W. G. Morris \& J. K. Pinto (Eds.), Wiley Guide to Managing Projects (pp. 1061-1086). Hoboken, New Jersey and Canada: John Wiley \& Sons, Inc.

[32]. ICF Consulting. (2003). California's future: it starts here UC's contributions to economic growth, health, and culture, an impact study for the University of California. San Francisco: ICF Consulting.

[33]. Ifinedo, P. (2005). Motivation and Job Satisfaction among Information Systems Developers - Perspectives from Finland, Nigeria and Estonia: A Preliminary Study. In O. Vasilecas, W. Wojtkowski, J. Zupančič, A. Caplinskas, W. G. Wojtkowski \& S. Wrycza (Eds.), Information Systems Development (pp. 161-172): Springer US.

[34]. Israel, G. D. (1992). Sampling Issues: Nonresponse. Gainesville: Program Evaluation and Organizational Development, IFAS,University of Florida.

[35]. Jaafar, M., Ramayah, T., \& Zainal, Z. (2006). Work Satisfaction and Work Performance: How Project Managers in Malaysia Perceive It. Academy of World Business, Marketing and Management Development Conference Proceedings, 2(113), 1305-1313.

[36]. Jibril, M. (1999). Current status and future plans for higher education in Nigeria Presented at the ADEA Working Group on Higher Education (WGHE) Meeting in Abuja, Nigeria. Abuja: ADEA Working Group on Higher Education.

[37]. Karwai, S. A. (2005). Motivation and Frustration in Organizations. Journal of Management and Social Sciences, 10, 97-106.

[38]. Kerr, C. (2001). The Uses of the University (5 ed.). Cambridge, MA: Harvard University Press.

[39]. Kirkman, B. L., Rosen, B., Tesluk, P. E., \& Gibson, C. B. (2004). The impact of team empowerment on virtual team performance: the moderating role of face-to-face interaction. Academy of Management Journal, 47(2), 175-192.

[40]. Kish, L. (1965). Survey Sampling. New York: John Wiley and Sons, Inc.

[41]. Locke, E. A., \& Latham, G. P. (1990). A theory of goal setting and task performance: Prentice Hall.

[42]. Locke, E. A., \& Letham, G. P. (2004). What should we do about motivation theory? six recommendations for the twenty-first century. Academy of Management Review, 29(3), 388 - 403.

[43]. Lumley, E. J., Coetzee, M., Tladinyane, R., \& Ferreira, N. (2011). Exploring the job satisfaction and organisational commitment of employees in the information technology environment. Southern African Business Review, 15(1), 100-118.

[44]. Luthans, F. (2002). Organizational behavior (9 ed.). New York: McGraw-Hill.

[45]. Lynn, S. K. (2002). The Winding Path: Understanding the Career Cycle of Teachers. The Clearing House: A Journal of Educational Strategies, Issues and Ideas, 75(4), 179-182. doi: 10.1080/00098650209604926

[46]. Mawoli, M. A., \& Babandako, A. Y. (2011). An evaluation of staff motivation, dissatisfaction and job performance in an academic setting. Australian Journal of Business and Management Research, 1(9), 1-13.

[47]. Miller, R., \& Chait, R. (2008). Teacher Turnover, Tenure Policies, and the Distribution of Teacher Quality:Can High-Poverty Schools Catch a Break? : Center for American Progress.

[48]. Moja, T. (2000). Nigeria education sector analysis: an analytical synthesis of performance and aain issues: The World Bank.

[49]. Morrison, R. L. (2008). Negative relationships in the workplace: Associations with organisational commitment, cohesion, job satisfaction and intention turnover. Journal of Management and Organization, 14(8), 330-344

[50]. Mowday, R. T., Steers, R. M., \& Porter, L. W. (1979). The measurement of organizational commitment. Journal of Vocational Behavior, 14(2), 224-247. doi: http://dx.doi.org/10.1016/0001-8791(79)90072-1

[51]. Mullins, L. J. (1996). Management and organisational behaviour (Fourh ed.). London: Pitman Publishing.

[52]. Nahapiet, J., \& Ghoshal, S. (1998). Social capital, intellectual capital, and the organizational advantage. Academy of Management Review, 23(2), 242-267.

[53]. National Universities Commission. (1994). Nigerian university system: past present and future A report prepared for the National Constitutional Conference Committee on Parastatals.

[54]. Nelson, D. L., \& Quick, J. C. (2003). Organizational behaviour: foundation, realities and challenges (4 ed.). Australia: Thomson South-Western.

[55]. New, S. J., \& Payne, P. (1995). Research frameworks in logistics: three models, seven dinners and a survey. International Journal of Physical Distribution and Logistics Management, 25(10), 60 - 77. doi: 10.1108/09600039510147663

[56]. OECD. (2011). Enhancing the contribution of universities to economic growth OECD Economic Surveys: Italy 2011 (E-book (PDF Format) ed., pp. 55-90): OECD Publishing.

[57]. Ololube, N. P. (2006). Teacher education, school effectiveness and improvement: A study of academic and professional qualification on teachers' job effectiveness in Nigerian secondary schools. (Doctoral Dissertation), University of Helsinki, Helsinki.

[58]. Ololube, N. P. (2007). The relationship between funding, ICT, selection processes, administration and planning and the standard of science teacher education in Nigeria. Asia-Pacific Forum on Science Learning and Teaching, 8(1), 1-29. 
[59]. Olutola, A. D. (1983). Cosmetic policies and the challenge of education for national development The Inaugural Lectures. 1lorin: University of llorin.

[60]. Peretomode, V. F. (1991). Educational Administration: Applied Concepts and Theoretical Perspectives for Students and Practitioners: Joja Educational Research and Publishers.

[61]. Pinder, C. C. (1998). Work motivation in organizational behavior: Prentice Hall.

[62]. Porter, L. W., \& Steers, R. M. (1973). Organizational, work, and personal factors in employee turnover and absenteeism. Psychological Bulletin, 80(2), 151-176. doi: 10.1037/h0034829

[63]. Power, D., \& Malmberg, A. (2008). The contribution of universities to innovation and economic development: in what sense a regional problem? Cambridge Journal of Regions, Economy and Society, 1(2), 233-245. doi: 10.1093/cjres/rsn006

[64]. Privateer, P. M. (1999). Academic Technology and the Future of Higher Education: Strategic Paths Taken and Not Taken. Journal of Higher Education, 70(1), 60-79. doi: 10.2307/2649118

[65]. Project Management Institute. (2000). A guide to the project management body of knowledge (PMBOK Guide) (2000 Edition ed.). Newtown Square, Pennsylvania, USA: Project Management Institute.

[66]. Quinn, J. B., Anderson, P., \& Finkelstein, S. (1996). Leveraging Intellect. Academy of Management Executive, 10(3), 7-27.

[67]. Russ, S., Chiang, B., Rylance, B. J., \& Bongers, J. (2001). Caseload in Special Education: An integration of research findings. Exceptional Children, 67(2), 161-172.

[68]. Saint, W., Hartnett, T. A., \& Strassner, E. (2003). Higher Education in Nigeria: A Status Report. Higher Education Policy, 16(3), 259-281. doi: 10.1057/palgrave.hep.8300021

[69]. Sempane, M., Rieger, H., \& Roodt, G. (2002). Job satisfaction in relation to organisational culture. South African Journal of Industrial Psychology, 28(2), 23-30.

[70]. Shu'ara, J. (2010). Higher education statistic: Nigeria's experience in data collection. Paper presented at the UNESCO Institute of Statistic Workshop on Education Statistic in Anglophone Countries Windhoek

[71]. Spector, P. E. (1997). Job satisfaction: application, assessment, causes, and consequences (Illustrated ed.). Thousand Oaks, CA: SAGE Publications.

[72]. Tharenou, P. (1993). A test of reciprocal causality of absenteeism. Journal of Organisational Behavior, 14(3), 269-290. doi: $10.1002 /$ job.4030140306

[73]. Ukeje, B. O., \& Ehiametalor, E. T. (1998). Crisis in Nigerian Education: The problem of Quality Crisis in Nigerian Education Guest Lecture Series Number 1. Nsugbe: Anambra State College of Education.

[74]. UNESCO. (2004). Final report of the Meeting of Higher Education Partners (World Conference on Higher Education + 5). Paris

[75]. Varghese, N. V. (2007, January-March, 2007). Higher education and development. International Institute for Educational Planning Newsletter, XXV, 1-3.

[76]. Vroom, V. H. (1964). Work and motivation. New York: John Wiley.

[77]. Wisniewski, L., \& Gargiulo, R. M. (1997). Occupational stress and burnout among special educators: a review of the literature. The Journal of Special Education, 31(3), 325-346. doi: 10.1177/002246699703100303

[78]. Woodhall, M. (1970). Cost-Benefit analysis in education Planning HEP. 141. Paris: UNESCO.

[79]. Zack, M. H. (1999). Developing a Knowledge Strategy. California Management Review, 41(3), 125-145. 
APPENDIX 2: Result of Kruskal-Wallis Test

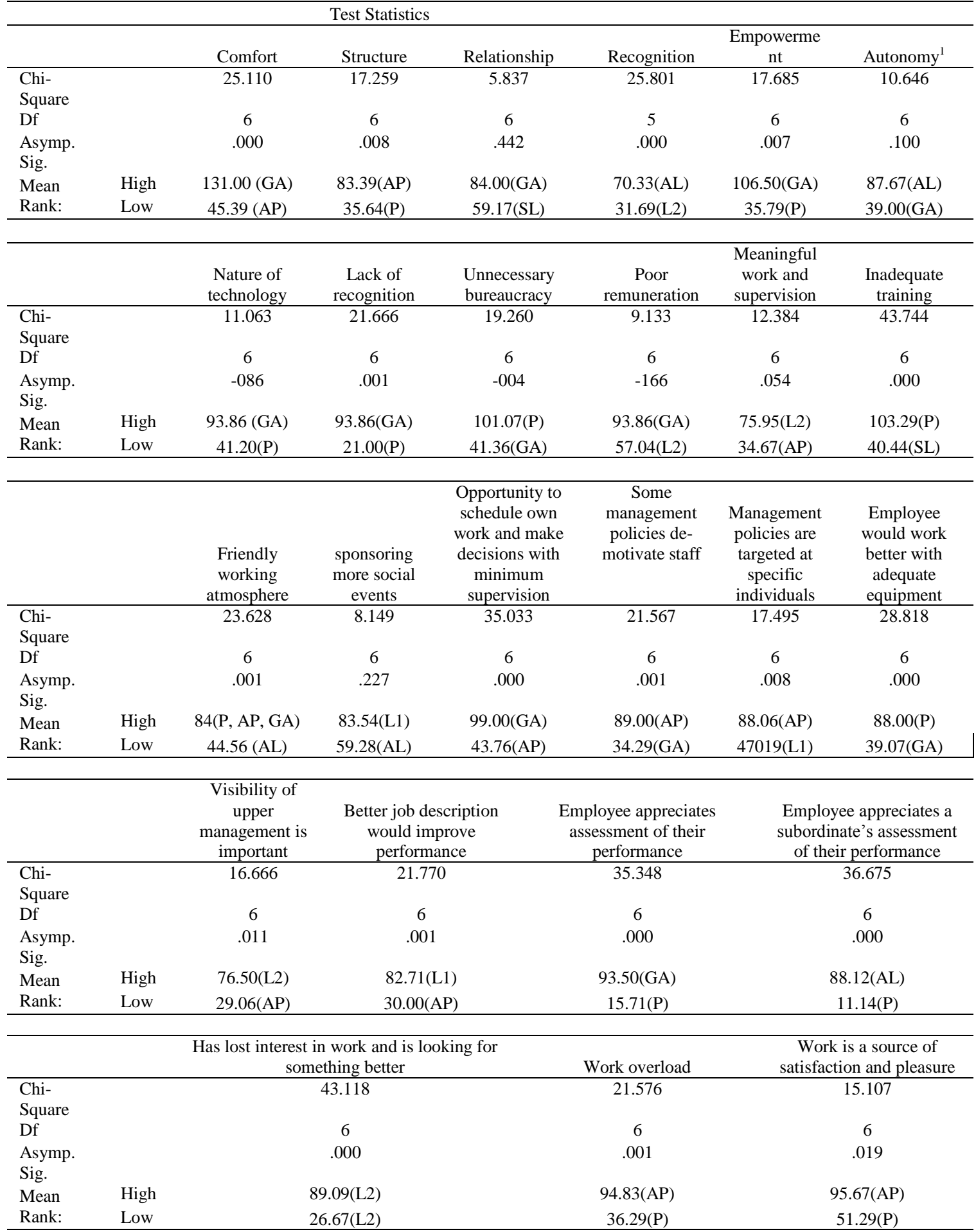

${ }^{1}$ Only GAs has less than 50 on autonomy, perhaps they are not confident working alone due to less of experience and academic qualification 